\title{
SISTEM PAKAR DIAGNOSA HAMA DAN PENYAKIT TANAMAN HOLTIKULTURA
}

\author{
Imelda Sri Dumayanti \\ Teknik Informatika, Fakultas Ilmu Komputer, \\ Universitas Methodist Indonesia \\ imeldasridumayanti.sinaga@gmail.com
}

\begin{abstract}
Consultation with someone who has expertise in a particular field in solving a problem is the right choice to get the best answers, suggestions, solutions, decisions or conclusions. Technological developments have an influence on developments in various sectors and technological advances have a lot of influence in the work process in agriculture, where a lot of agricultural equipment is developed so that the agricultural work process can be completed properly and provide better results in terms of quality and quantity. One technology that is widely developed is a technique that is able to adopt human thinking processes and ways, namely artificial intelligence technology (artificial intelligence). An expert system is one part of artificial intelligence that contains knowledge and experience that is entered by one or many experts into one knowledge. so that farmers can use the system to determine the right solution to the existing problems.
\end{abstract}

Keywords: Expert System, Onion Plants, Chili, Certainty Factor, PHP

\section{PENDAHULUAN}

Tanaman Cabai (Capsicum annum L.) merupakan tumbuhan perdu yang mempunyai rasa pedas, yang disebabkan kandungan capsaisin. Tanaman Cabai merupakan tanaman semusim, mempunyai adaptasi yang luas, serta dibutuhkan hampir tiap hari. Cabai merupakan salah satu komuditi agrobisnis pertanian atau perkebunan di Indonesia yang banyak diminati oleh para petani, hal ini disebabkan cabai memiliki nilai ekonomis tinggi yang banyak digunakan baik untuk konsumsi rumah tangga maupun untuk keperluan industri makanan. Makanan di Indonesia pada umumnya banyak menggunakan cabai, sehingga cabai menjadi komuditi yang sangat menjanjikan bagi petani.

Dalam lingkungan pertanian, hama penyakit merupakan masalah utama bagi para petani. Begitu pula pada tanaman Cabai dan Bawang. Hama penyakit yang menyerang tanaman Cabai dan Bawang ini sangat bervariasi sehingga sangat dibutuhkan seorang konsultan pertanian yang mampu mendiagnosa hama penyakit tanaman Cabai dan Bawang. Akan tetapi waktu dan biaya menjadi alasan bagi para petani Cabai dan Bawang untuk tidak konsultasi pada pakarnya sehingga terjadi kesalahan dalam memberikan solusi terhadap tanaman yang terserang hama.

\section{TINJAUAN LITERATUR}

Certainty Factor adalah suatu metode untuk membuktikan apakah suatu fakta itu pasti ataukah tidak pasti yang berbentuk metric yang biasanya digunakan dalam sistem pakar. Metode ini sangat cocok untuk sistem pakar yang mendiagnosis sesuatu yang belum pasti. Faktor kepastian (certainty factor) diperkenalkan oleh Shortlife Buchanan dalam Pembuatan MYCIN. Certainty Factor $(\mathrm{CF})$ merupakan nilai parameter klinis yang diberikan MYCIN untuk menunjukkan besarnya kepercayaan. Tahapan dalam merepresentasikan data kualitatif:
1. Kemampuan untuk mengekspresikan derajat keyakinan sesuai dengan metode yang sudah dibahas sebelumnya.

2. Kemampuan untuk menempatkan dan mengkombinasikan derajat keyakinan tersebut dalam sistem pakar. Dalam mengekpresikan derajat keyakinan digunakan suatu nilai yang disebut Certainty Factor (CF) untuk mengasumsikan derajat keyakinan seorang pakar terhadap suatu data.(Sihotang, 2014).

Tahapan dalam merepresentasikan data kualitatif:

1. Kemampuan untuk mengekspresikan derajat keyakinan sesuai dengan metode yang sudah dibahas sebelumnya.

2. Kemampuan untuk menempatkan dan mengkombinasikan derajat keyakinan tersebut dalam sistem pakar. Dalam mengekpresikan derajat keyakinan digunakan suatu nilai yang disebut Certainty Factor (CF) untuk mengasumsikan derajat keyakinan seorang pakar terhadap suatu data.

Metode certainty factor yang akan diterapkan dalam pembuatan sistem pakar ini adalah metode dengan rumus certainty factor sebagai berikut :

$\mathrm{CF}[\mathrm{H}, \mathrm{E}]=\mathrm{MB}[\mathrm{H}, \mathrm{E}]-\mathrm{MD}[\mathrm{H}, \mathrm{E}]$ Keterangan : $\mathrm{CF}(\mathrm{H}, \mathrm{E})=$ certainty factor hipotes $a$ yang dipengaruhi oleh evidence e diketahui dengan pasti

$\mathrm{MB}(\mathrm{H}, \mathrm{E})=$ measure of belief terhadap hipotesa $\mathrm{H}$, jika diberikan evidence E (antara 0 dan 1)

$\mathrm{MD}(\mathrm{H}, \mathrm{E})=$ measure of disbelief terhadap hipotesa $\mathrm{H}$, jika diberikan evidence E (antara 0 dan 1$) \backslash$

\section{a. Dengan Basis Pengetahuan}

Ada 2 cara untuk mendapatkan nilai faktor Kepastian atau $\mathrm{CF}$ yaitu:

Metode Net Belief

$\mathrm{CF}(\mathrm{H}, \mathrm{E})=\mathrm{MB}(\mathrm{H}, \mathrm{E})-\mathrm{MD}(\mathrm{H}, \mathrm{E})$

Keterangan : 
$\mathrm{CF}(\mathrm{H}, \mathrm{E})$ : Certainty Factor (Faktor Kepastian) dari hipotesis $\mathrm{H}$ yang dipengaruhi oleh gejala (evidence)

E Besarnya CF berkisar antara -1 sampai 1. Nilai -1 menunjukkan ketidakpercayaan mutlak sedangkan nilai 1 menunjukkan kepercayaan mutlak.

$\mathrm{MB}(\mathrm{H}, \mathrm{E})$ : $\quad$ Ukuran kenaikan kepercayaan (Measure of Belief) terhadap hipotesis $\mathrm{H}$ yang dipengaruhi oleh gejala E.

$\mathrm{MD}(\mathrm{H}, \mathrm{E})$ : Ukuran kenaikan ketidakpercayaan (Measure of Disbelief) terhadap hipotesis $\mathrm{H}$ yang dipengaruhi oleh gejala E. Perhitungan $\mathrm{CF}$ dikerjakan dengan ketentuan berikut.

$\mathrm{MB}=\mathrm{MB}$ Lama $+($ MB Baru * (1- MB Lama $))$

$\mathrm{MD}=\mathrm{MD}$ Lama $+($ MD Baru * (1-MD Lama) $)$

$\mathrm{CF}(\mathrm{H}, \mathrm{E})=\mathrm{MB}(\mathrm{H}, \mathrm{E})-\mathrm{MD}(\mathrm{H}, \mathrm{E})$

Keterangan:

Perasamaan satu mencari nilai MB akan digunakan secara terus menerus jika gejala yang ada lebih dari 2, dengan menjumlahkan dari gejala 1 dan 2, hasilnya akan dipakai untuk gejala 3, dan seterusnya. Sama juga untuk persamaan 2 mencari nilai MD rule nya sama seperti mencari nilai $\mathrm{MB}$.

$\mathrm{CF}(\mathrm{H}, \mathrm{E})$ : Certainty Factor (Faktor Kepastian) dari hipotesis $\mathrm{H}$ yang dipengaruhi oleh gejala (evidence) E. Besarnya CF berkisar antara -1 sampai 1. Nilai -1 menunjukkan ketidakpercayaan mutlak sedangkan nilai 1 menunjukkan kepercayaan mutlak.

$\mathrm{MB}(\mathrm{H}, \mathrm{E})$ : Ukuran kenaikan kepercayaan (Measure of Belief) terhadap hipotesis $\mathrm{H}$ yang dipengaruhi oleh gejala E.

$\mathrm{MD}(\mathrm{H}, \mathrm{E})$ : Ukuran kenaikan ketidakpercayaan (Measure of Disbelief) terhadap hipotesis $\mathrm{H}$ yang dipengaruhi oleh gejala E.

\section{b. Dengan Cara Mewancarai Seorang Pakar}

Nilai CF didapatkan dari interpretasi seorang pakar yang kemudian dirubah/dikonversi menjadi nilai CF dengan ketentuan pada Tabel 1.

Tabel 1 Nilai evidence tingkat keyakinan pakar

\begin{tabular}{|l|c|}
\hline Uncertainty term & CF \\
\hline Pasti tidak & -1 \\
\hline Hampir pasti tidak & $-0,8$ \\
\hline Kemungkinan besar tidak & $-0,6$ \\
\hline Mungkin tidak & $-0,4$ \\
\hline Tidak tahu & $-0,2$ sampai 0,2 \\
\hline Mungkin & 0,4 \\
\hline Kemungkinan besar & 0,6 \\
\hline
\end{tabular}

Perhitungan certainty factor secara umum mempresentasikan rule dalam bentuk sebagai berikut:

IF E1 AND E2 $A N D$ En

THEN H (CF Rule)

Atau
IF E1 AND E2 OR En

THEN H (CF Rule)

Dimana :

E1 ... E2 : Fakta-fakta (Evidence) yang ada

$\mathrm{H}$ : Hipotesis atau konklusi yang dihasilkan

CF Rule : Tingkat keyakinan terjadinya hipotesis $\mathrm{H}$ akibat adanya fakta-fakta $\mathrm{E}_{1} \ldots \mathrm{E}_{\mathrm{n}}$

Rule dengan evidence $\mathrm{E}$ tunggal dan Hipotesis $\mathrm{H}$

Tunggal (Certainty Factor Sequensial)

IF E THEN H (CF Rule)

$\mathrm{CF}(\mathrm{H}, \mathrm{E})=\mathrm{CF}(\mathrm{E}) \mathrm{X} \mathrm{CF}($ Rule $)$

Rule dengan evidence $\mathrm{E}$ ganda dan Hipotesis $\mathrm{H}$

Tunggal (Certainty Factor Paralel)

IF E1 AND E2 AND En THEN H (CF Rule)

$\mathrm{CF}(\mathrm{H}, \mathrm{E})=\min [\mathrm{CF}(\mathrm{E} 1)$,

$\mathrm{CF}(\mathrm{E} 2), \ldots ., \mathrm{CF}(\mathrm{En})] \times \mathrm{CF}($ Rule $)$

IF E1 OR E2 ......... OR En THEN H (CF Rule)

$\mathrm{CF}(\mathrm{H}, \mathrm{E})=\max [\mathrm{CF}(\mathrm{E} 1), \mathrm{CF}(\mathrm{E} 2), \ldots ., \mathrm{CF}(\mathrm{En})] \times \mathrm{CF}($ Rule $)$

Kombinasi dua buah rule dengan evidence berbeda (E1 dan E2), tetapi hipotesis sama

IF E1 THEN H Rule $1 \mathrm{CF}(\mathrm{H}, \mathrm{E} 1)=\mathrm{CF} 1=\mathrm{C}(\mathrm{E} 1) \mathrm{x}$

$\mathrm{CF}$ (Rule 1) IF E2 THEN $\mathrm{H}$

Rule $2 \mathrm{CF}(\mathrm{H}, \mathrm{E} 2)=\mathrm{CF} 2=\mathrm{C}(\mathrm{E} 2) \times \mathrm{CF}($ Rule 2$)$

$\mathrm{CF}(\mathrm{CF} 1, \mathrm{CF} 2)$ :

$\mathrm{CF} 1+\mathrm{CF} 2(1-\mathrm{CF} 1)$

$+\mathrm{CF} 2) /$

$1-(\min [|\mathrm{CF} 1|,|\mathrm{CF} 2| \quad$ jika $\mathrm{CF} 1<0$ atau $\mathrm{CF} 2<0$

$\mathrm{CF} 1+\mathrm{CF} 2(1+\mathrm{CF} 1) \quad$ jika CF1 $<0$ dan $\mathrm{CF} 2<0$

\subsection{Flowchart}

Flowchart dari Certainty Factor dapat dilihat pada gambar di bawah ini

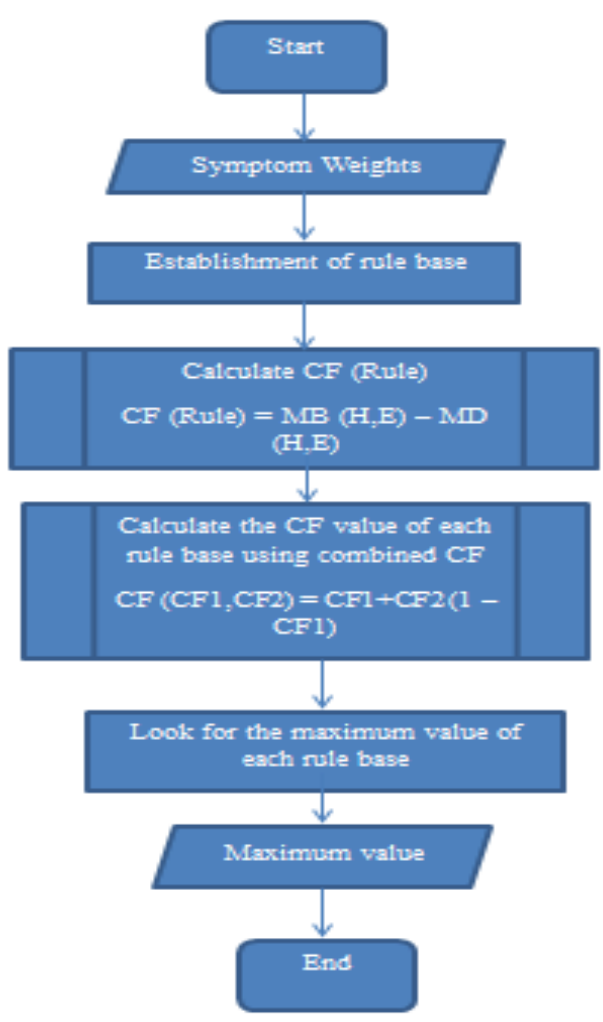

Gambar 1. Flowchart 


\section{PEMBAHASAN}

Sistem yang akan dibangun memanfaatkan sistem pakar dengan metode certainty factor untuk mendapatkan suatu kesimpulan hama dan penyakit yang diderita tanaman serta pencegahannya. Sistem pakar yang akan dibangun layaknya seorang pakar dalam mendapatkan kesimpulan dari permasalah-permasalahan (gejala) yang ada dengan keahlian pakar masing-masing. Sebelum sistem pakar ini dijalankan terdapat beberapa data yang dijadikan sebagai basis pengetahuan yaitu: data gejala, data penyakit, dan data nilai kemungkinan. Semua basis pengetahuan digunakan untuk memberikan kesimpulan diagnosa dari penyakit dan hama tanaman bawang dan cabai.

\section{Representasi Pengetahuan}

Tabel gejala-gejala yang terdapat pada Cabai, dapat dilihat pada Tabel 2

Tabel 2 Tabel Gejala-Gejala Pada Cabai

\begin{tabular}{|c|c|c|}
\hline id_ & kode & nama gejala \\
\hline 1 & G01 & Daun Menguning \\
\hline 2 & G02 & Warna jaringan akar coklat \\
\hline 3 & G03 & Warna jaringan batang coklat \\
\hline 4 & G04 & Akar membusuk \\
\hline 5 & G05 & Buah kecil \\
\hline 6 & G06 & Buah gugur \\
\hline 7 & G07 & Daun layu \\
\hline 8 & G08 & Jaringan sekuler bawang batang kecolatan \\
\hline 9 & G09 & Akar menjadi kecoklatan \\
\hline 10 & G10 & Warna buah kekuningan \\
\hline 11 & G11 & Buah membusuk \\
\hline 12 & G12 & Terdapat bercak bulat dan kering pada daun \\
\hline 13 & G13 & Bercak pada daun berwarna pucat sampai putih \\
\hline 14 & G14 & Bercak pada daun menyerupai mata kodok \\
\hline 15 & G15 & Terdapat bercak pada batang \\
\hline 16 & G16 & Bercak kecil coklat kehitaman pada buah \\
\hline 17 & G17 & Buah keriput \\
\hline 18 & G18 & Warna kulit buah seperti jerami padi \\
\hline 19 & G19 & Terdapat bercak kecil kebasah-basahan pada \\
\hline 20 & G20 & Buah mengering \\
\hline 21 & G21 & Biji yang terserang menjadi coklat \\
\hline 22 & $\mathrm{G} 22$ & Biji yang terserang menjadi keriput \\
\hline 23 & G23 & Daun melengkung ke bawah \\
\hline 24 & $\mathrm{G} 24$ & Daun berwarna hijau pekat \\
\hline 25 & G25 & Permukaan daun tidak rata \\
\hline 26 & G26 & Daun terkesan regas seperti kerupuk \\
\hline 27 & G27 & Daun mati \\
\hline 28 & G28 & Bunga dan Bakal buah berguguran \\
\hline 29 & G29 & Warna daun belang \\
\hline 30 & G30 & Daun cekung \\
\hline 31 & G31 & Daun mengeriting \\
\hline 32 & G32 & Daun memanjang \\
\hline
\end{tabular}

\begin{tabular}{|l|r|l|}
\hline 33 & G33 & Kebingungan mendadak \\
\hline 34 & G34 & Pertumbuhan tanaman terhambat \\
\hline 35 & G35 & Helai daun mengalami “vein clearing" \\
\hline 36 & G36 & Pucuk daun berwarna kuning jelas \\
\hline 37 & G37 & Tulang daun menebal \\
\hline 38 & G38 & Daun menggulung keatas \\
\hline 39 & G39 & Daun menyusut \\
\hline 40 & G40 & Warna daun berubah enjadi warna Tembaga / \\
\hline 41 & & kecoklatan \\
\hline 42 & G42 & Daun terpuntir \\
\hline 43 & G43 & Permukaan bawah bunga gugur \\
\hline 44 & G44 & Bercak daun berwarna putih \\
\hline 45 & G45 & Daun mengering \\
\hline 46 & G46 & Daun keriput \\
\hline 47 & G47 & Daun timbul benjolan seperti tumor \\
\hline 48 & G48 & Pucuk tanaman mati \\
\hline 49 & G49 & Tanaman menjadi keriput \\
\hline 50 & G50 & Warna daun \\
\hline 51 & G51 & Sel-sel dan jaringan daun rusak \\
\hline 52 & G52 & Bercak nekrotik pada daun \\
\hline 53 & G53 & Daun transparan \\
\hline 54 & G54 & Timbul lubang yang tidak beraturan pada buah \\
\hline 55 & G55 & Daun rusak \\
\hline 56 & G56 & Tanaman gundul \\
\hline 57 & G57 & Buah berlubang \\
\hline 58 & G58 & Terdapat titik coklat kehitaman pada pangkal \\
\hline 59 & G59 & Pangkal buah berlubang \\
\hline 60 & G60 & Buah jatuh ke tanah \\
\hline & & \\
\hline $56 e l$ & &
\end{tabular}

Tabel gejala-gejala yang terdapat pada tanaman bawang, dapat dilihat pada Tabel 3

Tabel 3 Tabel Gejala-Gejala Pada Tanaman Bawang

\begin{tabular}{|c|c|l|}
\hline id_gejala & kode & nama gejala \\
\hline 61 & G61 & $\begin{array}{l}\text { Pangkal batang menunjukkan bekas } \\
\text { initanulot }\end{array}$ \\
\hline 62 & G62 & Pangkal batang terpotong - potong \\
\hline 63 & G63 & Batang rebah \\
\hline 64 & G64 & Batang rusak dan berceceran \\
\hline 65 & G65 & $\begin{array}{l}\text { Daun bernoda putih mengkilat seperti } \\
\text { perak }\end{array}$ \\
\hline 66 & G66 & $\begin{array}{l}\text { Seluruh daun berwarna putih jika sudah } \\
\text { parah }\end{array}$ \\
\hline 67 & G67 & Umbi berukuran kecil \\
\hline 68 & G68 & Terdapat bintik-bintik putih pada daun \\
\hline 69 & G69 & Daun penuh dengan korokan \\
\hline 70 & G70 & Daun menjadi kering dan warna \\
\hline 72 & G72 & Bercak daun berwarna putih atau kelabu \\
\hline 73 & G73 & Bercak daun memebentuk zona \\
\hline 74 & G74 & Ujung daun kering \\
\hline 75 & G75 & Umbi membusuk \\
\hline 76 & G76 & Jaringan umbi mengering \\
\hline 77 & G77 & Ujung daun terdapat bercak hijau pucat \\
\hline
\end{tabular}




\begin{tabular}{|c|c|c|}
\hline 78 & G78 & $\begin{array}{l}\text { Terdapat miselium dan spora pada bercak } \\
\text { daun }\end{array}$ \\
\hline 79 & G79 & Tanaman kerdil \\
\hline 80 & G80 & Umbi berkerut \\
\hline 81 & G81 & Umbi berwarna kecoklatan \\
\hline 82 & G82 & $\begin{array}{l}\text { Bagian umbi dalam tampak kering dan } \\
\text { pucat }\end{array}$ \\
\hline 83 & G83 & Bercak daun bulat dan memanjang \\
\hline 84 & G84 & $\begin{array}{l}\text { Bercak daun berwarna coklat dengan tepi } \\
\text { menguning }\end{array}$ \\
\hline 85 & G85 & Jumlah bercak terbanyak pada ujung daun \\
\hline 86 & G86 & Jaringan pada bercak daun mati \\
\hline 87 & G87 & Bercak daun berwarna putih \\
\hline 88 & G88 & $\begin{array}{l}\text { Bercak daun melebar dan menjadi putih } \\
\text { kehijauan }\end{array}$ \\
\hline 89 & G89 & Tanaman mati mendadak \\
\hline 90 & G90 & Daun bawah rebah \\
\hline 91 & G91 & Pangkal daun mengecil \\
\hline 92 & G92 & Daun terpelintir \\
\hline 93 & G93 & Daun menguning \\
\hline 94 & G94 & Daun terkulai/layu \\
\hline 95 & G95 & $\begin{array}{l}\text { Dasar umbi terdapat cendawan keputih- } \\
\text { putihan }\end{array}$ \\
\hline 96 & G96 & Pangkal umbi berair \\
\hline 97 & G97 & Ujung daun busuk kebasah-basahan \\
\hline 98 & G98 & Ujung daun berwarna coklat \\
\hline 99 & G99 & Ujung daun mati \\
\hline 100 & G100 & $\begin{array}{l}\text { Lapisan umbi terdapat bercak merah } \\
\text { keunguan }\end{array}$ \\
\hline 101 & G101 & Lapisan umbi tampak basah \\
\hline 102 & G102 & Lapisan umbi terpisah-pisah \\
\hline 103 & G103 & Umbi berair \\
\hline 104 & G104 & $\begin{array}{l}\text { Tanaman menimbulkan bau busuk yang } \\
\text { menyengat }\end{array}$ \\
\hline 105 & G105 & Bentuk daun lebih kecil \\
\hline 106 & G106 & $\begin{array}{l}\text { Warna daun belang hijau pucat sampai } \\
\text { kekuningan }\end{array}$ \\
\hline 107 & G107 & Daun berpilin \\
\hline 108 & G108 & Terdapat puru berbentuk bulat pada akar \\
\hline 109 & G109 & Akar lebih pendek \\
\hline 110 & G110 & Rambut akar sedikit \\
\hline 111 & G111 & Tanaman lebih kaku \\
\hline 112 & G112 & Tanaman lebih kerdil \\
\hline 113 & G113 & Tanaman menguning \\
\hline 114 & G114 & Rambut akar sedikit \\
\hline 115 & G115 & Akar lebih sedikit \\
\hline 116 & G116 & Daun menebal \\
\hline
\end{tabular}

Tabel untuk penyakit dan hama pada tanaman bawang dan cabai yang akan dipakai pada sistem ini, tabel hama dan penyakit tanaman bawang dan cabai disatukan menjadi satu tabel, ditunjukkan oleh Tabel 4
Tabel 4 Tabel Hama Penyakit Pada Tanaman Bawang dan Cabai

\begin{tabular}{|c|c|c|}
\hline \begin{tabular}{|c|} 
id_ \\
penya \\
kit
\end{tabular} & kode & nama penyakit \\
\hline 1 & $\mathrm{P} 01$ & $\begin{array}{c}\text { Penyakit Layu Fusarium (Fusarium oxysporum } f . s p \\
\text { Melongenae Schlecht) }\end{array}$ \\
\hline 2 & $\mathrm{P} 02$ & $\begin{array}{l}\text { Layu Bakteri (Ralstonia (Pseudomonas } \\
\text { solanacearum } \\
\text { E.F.Sm) }\end{array}$ \\
\hline 3 & $\mathrm{P} 03$ & $\begin{array}{l}\text { Bercak Daun Cercospora (Cercospora capsici } \\
\text { Heald et Wolf) }\end{array}$ \\
\hline 4 & P04 & $\begin{array}{l}\text { Antraknosa/Penyakit Patek (Colletotrichum capsici } \\
\text { (Syd.) Bult. Et. Bisby) }\end{array}$ \\
\hline 5 & $\mathrm{P} 05$ & Busuk Buah (Fruit rot) \\
\hline 6 & P06 & Virus Kerupuk \\
\hline 7 & P07 & Virus Mosaik \\
\hline 8 & P08 & Virus kuning \\
\hline 9 & P09 & Tungau Kuning (Polyphagotarsonemus latus Banks) \\
\hline 10 & P10 & Trips (Thrips parvispinus Karny) \\
\hline 11 & P11 & Kutu Daun Persik (Myzus persicae Sulz.) \\
\hline 12 & $\mathrm{P} 12$ & Kutu Kebul (Bemisia tabaci) \\
\hline 13 & P13 & Ulat Grayak (Spodoptera litura F.) \\
\hline 14 & P14 & Ulat Buah (Helicoverpa armigera Hubner) \\
\hline 15 & P15 & Lalat Buah (Bactrocera sp) \\
\hline 16 & P16 & Penyakit Trotol, Bercak Ungu (Purple blotch) \\
\hline 17 & P17 & $\begin{array}{l}\text { Penyakit Embun Buluk/Tepung Palsu (Downy } \\
\text { mildew) }\end{array}$ \\
\hline 18 & $\mathrm{P} 18$ & $\begin{array}{l}\text { Enyakit Bercak daun Cercospora (Cercospora leaf } \\
\text { Spot) }\end{array}$ \\
\hline 19 & P19 & Penyakit otomatis, Antraknose (Antrachnose) \\
\hline 20 & $\mathrm{P} 20$ & $\begin{array}{l}\text { Penyakit Moler atau Layu Fusarium (Fusarium } \\
\text { Basal } \\
\text { Plate Rot) }\end{array}$ \\
\hline 21 & $\mathrm{P} 21$ & Mati pucuk \\
\hline 22 & P22 & $\begin{array}{l}\text { Virus Kerdil Kuning,Virus Mosaik (Onion Yellow } \\
\text { Dwarf Virus) }\end{array}$ \\
\hline 23 & $\mathrm{P} 23$ & Penyakit Buluk Penicilium (Blue Mold) \\
\hline 24 & $\mathrm{P} 24$ & Penyakit Nematoda Buncak Akar (Root Knot \\
\hline 25 & P25 & Ulat Bawang (Onion caterpillar, Beet armyworm) \\
\hline 26 & P26 & Hama Putih atau Trips (Thrips) \\
\hline 27 & $\mathrm{P} 27$ & Ulat Tanah (Cut Worm) \\
\hline 28 & $\mathrm{P} 28$ & Lalat Pengorok Daun (Liriomyza chinensis) \\
\hline
\end{tabular}

Perhitungan pada Metode Certainty Factor Tabel 5.

Tabel 5 Contoh Perhitungan Nilai CF

\begin{tabular}{|c|c|c|c|c|}
\hline No & $\begin{array}{c}\text { Nama } \\
\text { Penyakit }\end{array}$ & Gejala & MB & MD \\
\hline 1 & Busuk Buah & $\begin{array}{c}\text { Pangkal batang digigit } \\
\text { ulat }\end{array}$ & 0.8 & 0.01 \\
\hline & & $\begin{array}{c}\text { Pangkal batang } \\
\text { terpotong }\end{array}$ & 0.9 & 0.01 \\
\hline & & Batang rebah & 0.8 & 0.01 \\
\hline & & Batang rusak & 0.8 & 0.01 \\
\hline
\end{tabular}


Rumus menggunakan metode certainty factor sama seperti di bab 2 yang sudah dijelaskan, sebagai berikut $\mathrm{CF}=\mathrm{MB}-\mathrm{MD}$

$\mathrm{MB}=\mathrm{MB}$ Lama $+($ MB Baru $*(1-$ MB Lama $))$

$\mathrm{MD}=$ MD Lama $+($ MD Baru * $(1-$ MD Lama $))$

$\mathrm{MB}=(0.8+(0.9 *(1-0.8)))=0.98 \quad$ (untuk gejala $1 \&$ 2)

Nilai MB sementara akan dipakai untuk dijumlah kan dengan gejala 3

$\mathrm{MB}=(0.98+(0.8 *(1-0.98)))=0.996$

Nilai MB sementara yang didapatkan akan dipakai untuk gejala 4

$\mathrm{MB}=(0.996+(0.8 *(1-0.996)))=0.9992($ Nilai MB telah didapatkan) Selanjutnya untuk MD sama perhitungan seperti mencari nilai MB diatas

$\mathrm{MD}=(0.01+(0.01 *(1-0.01)))=0.0199 \quad$ (untuk gejala $1 \& 2)$ Nilai MD sementara akan dipakai untuk dijumlahkan untuk gejala 3

$\mathrm{MD}=(0.0199+(0.01 *(1-0.0199)))=0.029701$

Nilai MD sementara yang didapatkan akan dipakai untuk gejala 4

$\operatorname{MD}(0.029701+(0.01 *(1-0.029701)))=0.03940399$

(Nilai MD telah didapatkan) $\mathrm{CF}=\mathrm{MB}-\mathrm{MD}$

$$
\begin{aligned}
& =0.9992-0.03940399 \\
& =0.959796 * 100 \% \\
& =95,97 \%(\text { Nilai CF })
\end{aligned}
$$

Tabel Pengetahuan nilai kepastian merupakan tabel yang berisikan nilai kepastian dari ahli (pakar) untuk setiap penyakit dan hama tanaman bawang ditunjukkan oleh Tabel 6.

Tabel 6. Pengetahuan Nilai Kepastian (Certainty Factor) Untuk Hama Penyakit Tanaman Bawang dan Cabai

\begin{tabular}{|c|c|c|c|c|}
\hline $\begin{array}{c}\text { id_ } \\
\text { pengetah } \\
\text { uan }\end{array}$ & $\begin{array}{c}\text { id_penyaki } \\
\mathrm{t}\end{array}$ & id_gejala & $\mathrm{mb}$ & $\mathrm{md}$ \\
\hline 1 & 1 & 2 & 0.9 & 0.02 \\
\hline 2 & 1 & 4 & 0.8 & 0.1 \\
\hline 3 & 2 & 9 & 0.9 & 0.01 \\
\hline 4 & 24 & 114 & 0.8 & 0.01 \\
\hline 5 & 24 & 115 & 0.9 & 0.02 \\
\hline 6 & 1 & 3 & 0.8 & 0.01 \\
\hline 7 & 2 & 8 & 0.9 & 0.01 \\
\hline 8 & 3 & 12 & 0.9 & 0.02 \\
\hline 9 & 25 & 61 & 0.8 & 0.01 \\
\hline 10 & 25 & 62 & 0.9 & 0.01 \\
\hline 11 & 25 & 63 & 0.8 & 0.01 \\
\hline 12 & 25 & 64 & 0.8 & 0.01 \\
\hline 13 & 27 & 61 & 0.8 & 0.02 \\
\hline 14 & 27 & 63 & 0.9 & 0.01 \\
\hline 15 & 27 & 64 & 0.9 & 0.02 \\
\hline 16 & 19 & 89 & 0.8 & 0.01 \\
\hline 17 & 23 & 104 & 0.8 & 0.02 \\
\hline 18 & 24 & 113 & 0.9 & 0.01 \\
\hline 19 & 24 & 112 & 0.9 & 0.02 \\
\hline 20 & 24 & 111 & 0.8 & 0.01 \\
\hline
\end{tabular}

\begin{tabular}{|c|c|c|c|c|}
\hline 21 & 10 & 48 & 0.8 & 0.02 \\
\hline 22 & 11 & 49 & 0.9 & 0.01 \\
\hline 23 & 11 & 12 & 0.9 & 0.02 \\
\hline 24 & 7 & 34 & 0.8 & 0.01 \\
\hline 25 & 1 & 5 & 0.8 & 0.02 \\
\hline 26 & 1 & 6 & 0.9 & 0.01 \\
\hline 27 & 2 & 10 & 0.9 & 0.02 \\
\hline 28 & 2 & 11 & 0.8 & 0.01 \\
\hline 29 & 4 & 16 & 0.8 & 0.02 \\
\hline 30 & 5 & 19 & 0.9 & 0.01 \\
\hline 31 & 5 & 20 & 0.9 & 0.02 \\
\hline 32 & 5 & 17 & 0.8 & 0.01 \\
\hline 33 & 5 & 21 & 0.8 & 0.02 \\
\hline 34 & 13 & 57 & 0.9 & 0.01 \\
\hline 35 & 6 & 28 & 0.9 & 0.02 \\
\hline 36 & 13 & 53 & 0.8 & 0.01 \\
\hline 37 & 9 & 31 & 0.8 & 0.02 \\
\hline
\end{tabular}

Tabel solusi penyakit, berisi idpenyakit dan id, kode dari

\begin{tabular}{|c|c|c|}
\hline Kode & Idpenyakit & idsolusi \\
\hline 1 & 1 & S01 \\
\hline 2 & 2 & S02 \\
\hline 3 & 3 & S03 \\
\hline 4 & 4 & S04 \\
\hline 5 & 5 & S05 \\
\hline 6 & 6 & S06 \\
\hline 7 & 7 & S07 \\
\hline 8 & 8 & S08 \\
\hline 9 & 9 & S09 \\
\hline 10 & 10 & $\mathrm{~S} 10$ \\
\hline 11 & 11 & S11 \\
\hline 12 & 12 & S12 \\
\hline 13 & 13 & S13 \\
\hline 14 & 14 & S14 \\
\hline 15 & 15 & $\mathrm{~S} 15$ \\
\hline 16 & 16 & S16 \\
\hline 17 & 17 & S17 \\
\hline 18 & 18 & S18 \\
\hline 19 & 19 & S19 \\
\hline 20 & 20 & S20 \\
\hline 21 & 21 & S21 \\
\hline 22 & 22 & S22 \\
\hline 23 & 23 & S23 \\
\hline 24 & 24 & S24 \\
\hline 25 & 25 & $\mathrm{~S} 25$ \\
\hline 26 & 26 & S26 \\
\hline 27 & 27 & S27 \\
\hline 28 & 28 & $\mathrm{~S} 28$ \\
\hline
\end{tabular}
solusi, ditunjukkan pada Tabel 7

Tabel 7 Tabel Solusi Penyakit 
Tabel solusi berisi informasi solusi untuk hama dan penyakit tanaman bawang dan cabai, di tunjukkan pada Tabel 8.

Tabel 8. Tabel Solusi

\begin{tabular}{|c|c|}
\hline Kode & Solusi \\
\hline 1 & $\begin{array}{l}\text { Sanitasi dengan mencabut dan memusnahkan tanaman } \\
\text { terserang, Dianjurkan memanfaatkan agen antagonis } \\
\text { Trichoderma spp. dan Gliocladium spp. serta } \\
\text { perpenggunaan Fungisida }\end{array}$ \\
\hline 2 & $\begin{array}{l}\text { Dianjurkan memanfaatkan agen antagonis } \\
\text { Trichoderma spp. dan Gliociadum spp. yang } \\
\text { diaplikasikan bersamaan dengan pemupukan dasar. } \\
\text { Dan penggunaan bakterisida sesuai anjuran sebagai } \\
\text { alternatif terakhir }\end{array}$ \\
\hline 3 & $\begin{array}{l}\text { Melakukan penyemprotan fungisida Antracol, } \\
\text { Starmil atau score. Perlakuan benih sebelum tanam, } \\
\text { perbaikan drainase }\end{array}$ \\
\hline 4 & Pengendalian dengan penyemprotan fungisida \\
\hline 5 & $\begin{array}{l}\text { Penggunaan benih unggul yang tahan terhadap } \\
\text { bakteri Penyemprotan bakterisida dengan dosis dan } \\
\text { cara yang tepat Penyemprotan Fungisida } \\
\text { antracol,cozeb,Bion-M. }\end{array}$ \\
\hline 6 & $\begin{array}{l}\text { Mengendalikan serangga vektor, misalnya dengan } \\
\text { asefat atau imidakloprit } 2 \mathrm{x} \text { (saat tanam dan } 45 \text { hari } \\
\text { setelah tanam). } \\
\text { Menanam bunga matahari atau jarak kepyar sebagai } \\
\text { pagar pembatas disekitar bedengan untuk mencegah } \\
\text { B. tabaci }\end{array}$ \\
\hline 7 & $\begin{array}{l}\text { Mengganti tanaman yang terinfeksi dan } \\
\text { penyemmprotan insektisida secara rutin }\end{array}$ \\
\hline 8 & $\begin{array}{l}\text { Penanggulangannya dengan cara memilih bibit } \\
\text { unggul yang tahan terhadap virus gemini, dan } \\
\text { membasmi vektornya/penularnya yakni kutu kebul } \\
\text { dan kutu daun }\end{array}$ \\
\hline 9 & $\begin{array}{l}\text { Penyemprotan rutin dengan racun tungau (Akarisida) } \\
\text { misalnya } \\
\text { Agrimec, Demolish, Pegasus, Bamex, Omite,Mitac }\end{array}$ \\
\hline 10 & $\begin{array}{l}\text { Penyemprotan rutin dengan insektisida Agremic, } \\
\text { Demolish, Pegasus, Bamex,Oxmite, Mitac atau } \\
\text { Samite }\end{array}$ \\
\hline 11 & $\begin{array}{l}\text { Pengendalian dengan disemprot insektisida berbahan } \\
\text { aktif abamektin, fipronil atau diafenthurion }\end{array}$ \\
\hline 12 & $\begin{array}{l}\text { Pemanfaatan musuh alami, seperti predator, } \\
\text { parasitoid, dan patogen serangga. }\end{array}$ \\
\hline & $\begin{array}{l}\text { Sanitasida lingkungan, Penggunaan pestisida selektif } \\
\text { sebagai alternatif terakhir antara lain } \\
\text { Permethrin,Amitraz,Fenoxycarb,Imidacloprid,Bifent } \\
\text { hrin,Deltamethrin, Buprofezin, Endosulphan dan } \\
\text { asefat. }\end{array}$ \\
\hline 13 & Semprot dengan Curacron, Regent, Prevathon atau \\
\hline 14 & $\begin{array}{l}\text { Menyemprotkan agen hayati sebagai pengendalian } \\
\text { biologis seperti } \\
\text { Bacillus thuringiensis. } \\
\text { Pengendalian kimia dengan penyemprotan bahan } \\
\text { aktif klorpirifos,permetrin,karbaril. }\end{array}$ \\
\hline 15 & $\begin{array}{l}\text { Pengendalian dengan membuat perangkap lalat buah } \\
\text { atau disemprot insektisida Curacron, Regent,Santoat } \\
\text { atau Matador. }\end{array}$ \\
\hline 16 & $\begin{array}{l}\text { Melakukan penyemprotan fungisida kontak berbahan } \\
\text { aktif macozeb selama } 3 \text { hari berturut-turut serta } \\
\text { gunakan fungisida sistemik berbahan aktif } \\
\text { dimetomorf }\end{array}$ \\
\hline 17 & $\begin{array}{l}\text { Menggunakan fungisida sistemik berbahan aktif } \\
\text { difekonazol dan fungisida translaminar seperti trivia } \\
\text { yang mampu menembus daun dan mencapai bagian } \\
\text { bawah permukaan daun. }\end{array}$ \\
\hline
\end{tabular}

\begin{tabular}{|c|c|}
\hline 18 & $\begin{array}{l}\text { Pengendalian dilakukan dengan rotasi tanaman, } \\
\text { mengatur aerasi lahan, membersihkan daun yang } \\
\text { terserang, dan penyemprotan fungisida } \\
\text { bahan aktif difenokonazol, mankozeb, metalaksil, dll. }\end{array}$ \\
\hline 19 & $\begin{array}{l}\text { Melakukan penyemmprotan fungisida sistemik } \\
\text { berbahan aktif dimetomorf atau difekonazole, lalu } \\
\text { penyemprotan fungisida kontak berbahan aktif } \\
\text { propineb selama } 3 \text { hari berturut-turut. }\end{array}$ \\
\hline 20 & $\begin{array}{l}\text { Dengan pemberian trichoderma sp pada pupuk dasar } \\
\text { maupun dengan cara dikocor maka cendawan } \\
\text { fusarium bisa ditekan perkembangannya. } \\
\text { Trichoderma sp berguna sebagai dekomposer pupuk } \\
\text { menjadi } C \text { organik }\end{array}$ \\
\hline 21 & $\begin{array}{l}\text { Mengurangi pemakaian pupuk nitrogen (urea atau } \\
\text { ZA) } \\
\text { Menanam dengan jarak tidak terlalu rapat tujuannya } \\
\text { supaya sirkulasi udara lancar. } \\
\text { Membuang atau membakar tanaman yang terserang. }\end{array}$ \\
\hline 22 & $\begin{array}{l}\text { Penanaman umbi yang bebas virus dan ditanam } \\
\text { didaerah bebas virus yang } \\
\text { letaknya jauh dari sumber penyakit, pergiliran } \\
\text { tanaman selain jenis } \\
\text { Allium } \\
\text { dan mencabut tanaman yang terserang. } \\
\text { Eradikasi tanaman yang menunjukkan gejala } \\
\text { serangan }\end{array}$ \\
\hline 23 & $\begin{array}{l}\text { Pergiliran tanaman dengan jenis tanaman lain serta } \\
\text { menjaga drainase agar tanah tidak terlalu becek. } \\
\text { Pemberian lampu dan kipas angin agar tidak mudah } \\
\text { lembab pada saat melakukan penyimpanan. }\end{array}$ \\
\hline 24 & $\begin{array}{l}\text { Sterilisasi lahan sebelum proses penanaman, } \\
\text { pengaturan sistem pengairan/ drainase dan kondisi } \\
\text { kelembapan dipertahankan dengan baik }\end{array}$ \\
\hline 25 & $\begin{array}{l}\text { Sanitasi gulma karena dapat menarik serangga betina } \\
\text { untuk meletakkan telur, pengumpulan larva } \\
\text { kemudian memusnahkannya, } \\
\text { pengolahan lahan untuk membongkar persembunyian } \\
\text { ulat. }\end{array}$ \\
\hline & Memanfaatkan predator ulat tanah, yaitu burung \\
\hline 26 & $\begin{array}{l}\text { Penyiraman dilakukan pada siang hari untuk } \\
\text { menghilangkan nimfa trips yang menempel pada } \\
\text { daun dan menurunkan suhu disekitar tanaman. } \\
\text { Apabila populasi dan serangan terus meningkat } \\
\text { (belum ada ambang pengendaliannya) dilakukan } \\
\text { pengendalian dengan insektisida efektif yang telah } \\
\text { resmi terdaftar oleh Menteri Pertanian, seperti : } \\
\text { Padan 50 } \\
\text { SP. }\end{array}$ \\
\hline 27 & $\begin{array}{l}\text { Penyiraman dilakukan pada siang hari untuk } \\
\text { menghilangkan nimfa trips yang menempel pada } \\
\text { daun dan menurunkan suhu disekitar tanaman. } \\
\text { Memanfaatkan predator ulat tanah,yaitu burung. }\end{array}$ \\
\hline 28 & $\begin{array}{l}\text { Menjaga kebersihan lingkungan tanaman dengan } \\
\text { cara penyiangan atau membersihkan gulma dan } \\
\text { rumput liar } \\
\text { Menanam pada lokasi yang jauh dari tanaman inang. } \\
\text { Penyemprotan insektisida yang bekerja seecara } \\
\text { kontak, misalnya agrimec,alfamex,demolish atau } \\
\text { curacon. }\end{array}$ \\
\hline
\end{tabular}

\section{Perancangan Sistem}

\section{Use Case Diagram}

Use Case Diagram merupakan kumpulan diagram dan text yang saling bekerjasama untuk mendokumentasikan bagaimana user (actor) berinteraksi dengan system. 
Gambar 2 merupakan use case diagram dari program yang akan dirancang :

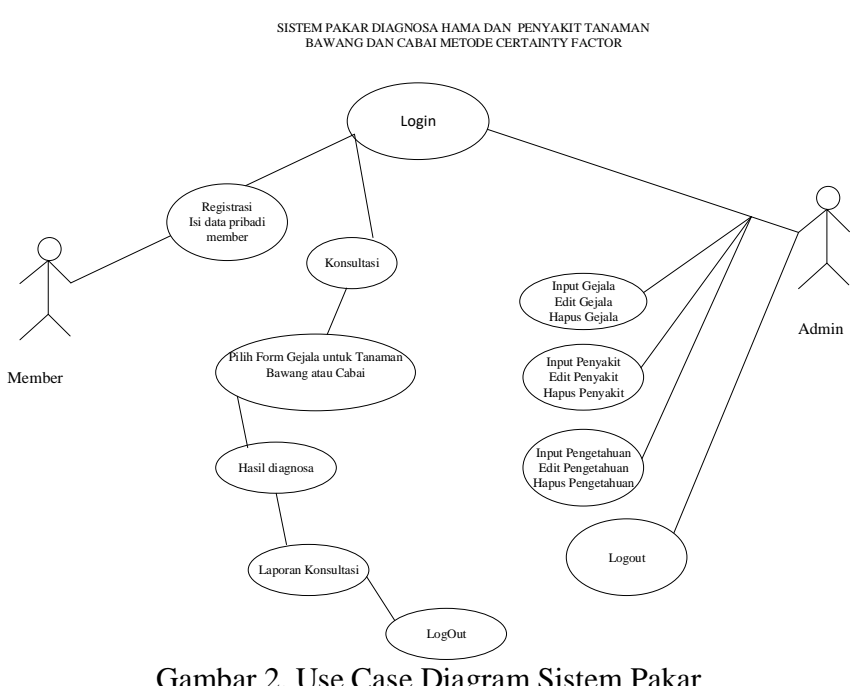

Gambar 2. Use Case Diagram Sistem Pakar

\section{Class Diagram}

Class Diagram adalah sebuah spesifikasi yang jika diinisialisasi akan menghasilkan sebuah objek dan merupakan inti dari pengembangan dan desain berorientasi objek. Class menggambakan keadaan (atribut/properti) suatu sistem, sekaligus menawarkan layanan untuk memanipulasi keadaan tersebut (metode/fungsi). Class diagram sistem pakar ini dapat dilihat pada Gambar 3

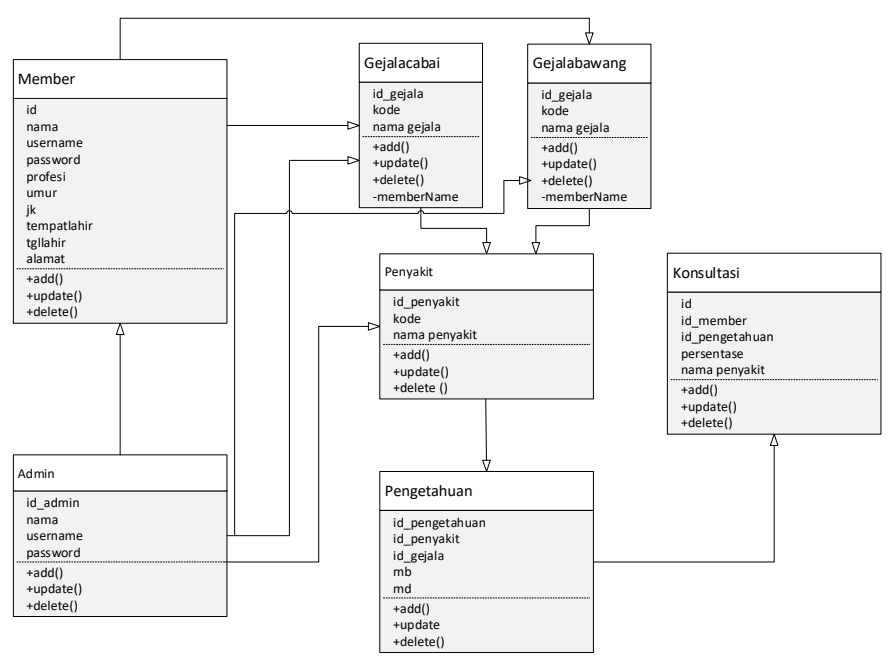

Gambar 3 Class Diagram Sistem Pakar

\section{Activity Diagram}

Activity diagram menggambarkan berbagai alir aktivitas dalam sistem yang sedang dirancang, bagaimana masing-masing alir berawal, Decision yang mungkin terjadi, dan bagaiman mereka berakhir. Activity Diagram juga dapat menggambarkan proses paralel yang mungkin terjadi pada beberapa eksekusi. Activity diagram dapat dilihat pada Gambar 4

\section{Activity Diagram Form Input Data Admin, dapat dilihat pada Gambar 4}

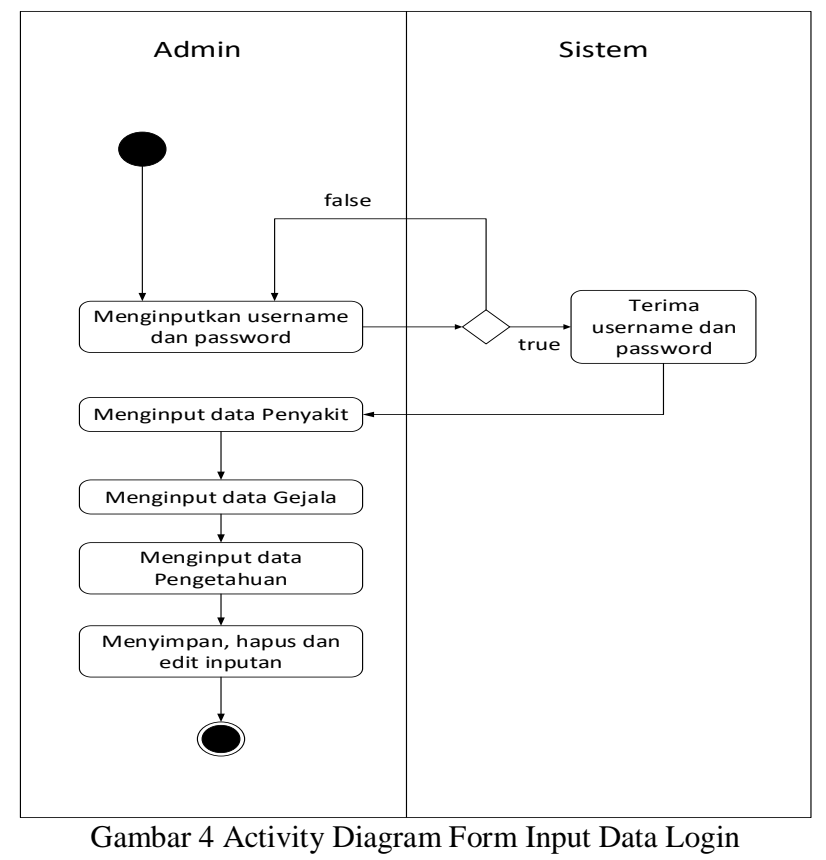

2. Activity Diagram Form Input Data Member, dapat dilihat pada Gambar 5

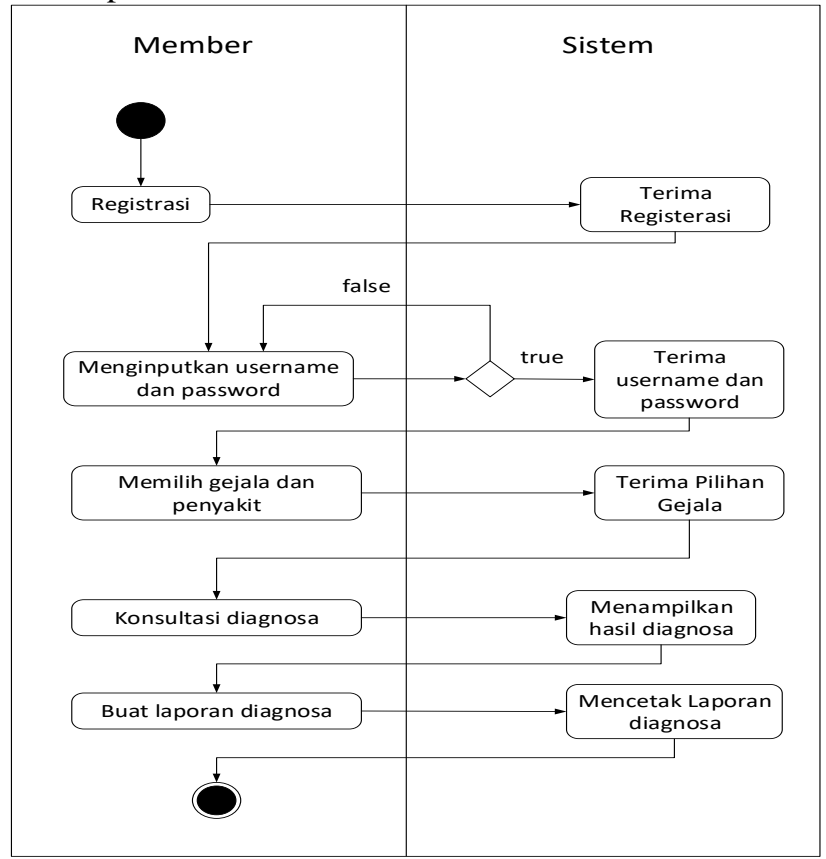

Gambar 5 Activity Diagram Form Input Data Member

\section{KESIMPULAN}

Berdasarkan hasil analisa dan pembahasan hasil penelitian, kesimpulan yang dapat diambil adalah :

1. Besarnya nilai $\mathrm{CF}$ total ditemukan oleh banyaknya kecocokan antara gejala yang dipilih dengan hama/penyakit, serta besarnya nilai $\mathrm{CF}$ tiap aturan pada kaidah diagnosa.

2. Telah berhasil dibangun sebuah sistem "Sistem Pakar Diagnosa Hama Dan Penyakit Tanaman Bawang Dan Cabai Metode Certainty Factor" untuk membantu petani dalam mengidentifikasi penyakit yang disebabkan oleh hama pada cabai dan tanaman bawang berdasarkan gejala-gejala yang di berikan. 
3. Sistem pakar diharapkan dapat bermanfaat bagi petani untuk mengetahui informasi tentang penyakit dan hama tanaman cabai dan bawang

4. Hasil pengujian/diagnosa menunjukkan bahwa sistem pakar yang dibangun telah berjalan sesuai yang diharapkan

5. Aplikasi yang sudah dibangun mempunyai kelebihan yang diperoleh dari website sistem pakar diagnosa hama dan penyakit tanaman bawang dan cabai metode certainty factor ini sebagai berikut :

a. Mempermudah petani dalam mendeteksi hama dan penyakit yang ada pada tanaman bawang dan cabai nya.

b. Mempunyai sistem pakar yang dapat membantu pengguna untuk diagnosa tanaman bawang dan cabai dengan memilih gejala-gejala yang ada.

\section{DAFTAR PUSTAKA}

[1] Rosnelly,Rika.2017.Sistem Pakar konsep dan teori. Yogyakarta.Andi Publisher

[2] Pratiwi, Heny.2019.Buku Ajar Sistem Pakar.Samarinda.Goresan Pena

[3] Meilin, Araz., 2014.Hama Dan Penyakit Pada Tanaman Cabai Serta Pengendaliannya. Jambi: Balai Pengkajian Teknologi Pertanian Jambi

[4] Wiro Sasmito, Ginanjar.2017. Sistem Pakar Diagnosis Hama dan Penyakit Tanaman Hortikultura dengan Teknik Inferensi Forward dan Backward Chaining.Jurnal Pelita Harapan Bersama. Tegal.

[5] Moekasan, Tonny K dkk.,2015. Modul Pelatihan Budidaya Cabai Merah, Tomat, dan Mentimun Berdasarkan Konsepsi Pengendalian Hama Terpadu Sub title. Bandung : Nikardi Gunandi dan Asih K. Karjadi

[6] Burhannudin,Muhammad, Suprapto, Nurul Hidayat.2017.Pemodelan Sistem Pakar Diagnosis Penyakit Tanaman Apel Manalagi dengan Metode Backward Chaining Menggunakan Certainty Factor. Jurnal Universitas Brawijaya. Malang

[7] Penelitian, Pusat Pengembangan, D A N., 2018. Organisme Pengganggu Tumbuhan (Opt) Bawang Merah. Jakarta: Badan Penelitian dan Pengembangan Pertanian.

[8] Sihotang, Hengki.2014. Sistem Pakar Mendiagnosa Penyakit Kolesterol Pada Remaja dengan Metode Certainty Factor (CF) Berbasis Web. Jurnal STMIK Pelta Nusantara Medan. Medan.

[9] Azzamy. 2015. Cara Mengendalikan Hama dan Penyakit Tanaman Cabe. Terdapat pada: https://mitalom.com/caramengendalikan-hama-dan-penyakit-tanaman-cabe/ [Diakses 26 April 2020]

[10] Sutati, Emi, 2019. Cara Mengatasi Penyakit Tanaman Pada Bawang Merah. Terdapat pada http://cybex.pertanian.go.id/mobile/artikel/73318/CaraMengatasi-Penyakit-Tanaman-Pada-Bawang-Merah/ [Diakses 26 April 2020]

[11] Hama, Klinik, 2016. Mengatasi Serangan Ulat Cabai. Terdapat pada: https://benihpertiwi.co.id/mengatasiserangan-hama-ulat-pada-cabai/\#.XxOdo-dS_Dd [Diakses 26 Aprli 2020]

[12] Rina Miranda, dkk. 2016. Sistem Pakar Mendiagnosa Penyakit Jamur Akar Putih (Riqidoporus Lignosus) Pada Tanaman Karet (Havea Brasiliensis) dengan Metode Certainty Factor. Jurnal STMIK Budi Darma. Medan.

[13] Tomi Winanto, dkk. 2018. Sistem Pakar Diagnosa Hama dan Penyakit Tanaman Cabai Besar Menggunakan Metode Certainty Factor. Jurnal STMIK Sinar Nusantara Surakarta. Surakarta.
[14] Agus, Fahrul, Wulandari, Hernandha Eka,Astuti, Indah Fitri. 2017. Expert System With Certainty Factor For Early Diagnosis Of Red Chill Peppers Disesases. Computer Science Dept. Faculty of CSIT Mulawarman University. Samarinda

[15] Kristianto Eko Winarno. 2019. Sistem Pakar Diagnosis Penyakit Tanaman Bawang Merah Menggunakan Metode Certainty Factor dengan Mesin Inferensy Forwward Chaining Berbasis Web. Jurnal Institut Teknologi Nasional Malang. Malang. 